\title{
The Influence of Teachers on Teaching Performance and the Conduct of Leadership
}

\author{
Yenti $^{\left.1^{*}\right)}$, Happy Fitria ${ }^{2}$, Syaiful Eddy ${ }^{2}$ \\ ${ }^{I}$ SD Negeri 3 Setia Jaya \\ ${ }^{2}$ Universitas PGRI Palembang \\ *Corresponding author. Email: yentiyen0@gmail.com
}

\begin{abstract}
This research is intended to investigate and describe: (1) the effect of the principal conduct on teacher teaching performance; (2) the impact of Teacher Work Ethics on teacher performance; and (3) the effects of leader behavior; and teacher work ethics on teacher performance. The study findings indicated: 1) that lead behavior has an impact on the teacher's teaching performance; 2) teacher work ethics has an effect on the teacher's teaching achievement; 3) that leading leadership conduct and teacher work have an influence on teacher teaching behavior.
\end{abstract}

Keywords: Leadership, Work Ethics, Performance Teaching

\section{INTRODUCTION}

School as an educational organization has several important aspects to always be developed in an effort to keep the school's existence still having its existence in society and the world of education. These aspects that need to be developed include aspects of defining goals, determining policies, developing programs, hiring people, providing facilities, achieving results and coordinating separate activities [1]. In line with Dahlan, et al [2], school is a system where there is a process of interaction between school principals, teachers, employees, supervisors, school committees, and students. All of these are important influences in the formation of human resources. In line with the opinion of Fitria, et al [3], a school is an institution that is prepared to provide the needs of quality human resources. Quality human resources will improve the quality of a country.

As a school principal who has a vital meaning in the educational process, the principal must cultivate and utilize all available human resources to achieve school effectiveness that creates change. The conduct of the principal must be able to promote the teachers' success, both as a group and in a welcoming manner. Furthermore, according to the opinion of Alhusaini, et al [4] the principal as a leader of an educational institution must understand thoroughly how to manage his managerial abilities in an educational institution to bring the school, he leads into a school that is able to compete and still be cultured in the age of globalization. Because educational institutions are a production that will produce quality human resources who will become the backbone of the implementation of national development.

Thus, a teacher is required to carry out his profession professionally accompanied by having a high work ethic and good performance will certainly affect the quality and quality of education. Work ethic can be defined as attitudes and views towards work, work habits, characteristics or traits regarding the work methods of a person, a human group or a nation. Work ethic is a fundamental attitude towards themselves and their world which is reflected in the real world. However, if the work ethic will decrease, then the results of the work (performance) for which they are responsible will not be maximized and the achievement of organizational goals will not be maximally achieved. For this reason, teacher performance must always be improved. In line with the opinion of Damayani, et al [5] efforts to improve performance are usually carried out by providing motivation, providing supervision, providing incentives, providing good opportunities to develop in a career, increasing abilities, good leadership styles, and other relevant efforts.

Based on the results of observations on pre-research activities at SD Negeri 1 Jirak, SD Negeri 2 Jirak, SD Negeri 1 Setia Jaya, SD Negeri 2 Setia Jaya, and SD Negeri Bangkit Jaya, which were used as research objects, the leadership behaviour of the principal is still lacking in carrying out various activities. done by the 
teacher both outside and inside the classroom. In addition, every school principal holds an activity in the school does not do it by involving other school members (socializing), some principals do not motivate teachers to improve their work ethic, this is because there are still teachers who are late entering the classroom, there are still complaints when teachers get a lot of assignments, they are less effective in carrying out their duties such as planning, implementing, the evaluation (evaluation) of the educational and learning process is still poor besides the teacher's work ethic and still maintains a school atmosphere model that does not pay attention to core values (for example, low discipline, low attitudes to work, lack of dedication and loyalty to work and applicable regulations), and the emergence of a culture of caring less will result in the decline in the quality of education in schools.

Teachers' low teaching performance will affect the implementation of tasks, which will also affect the achievement of educational quality goals. With their leadership behaviour, the principal can build and maintain a positive and quality teacher teaching performance. According to Suryosubroto [6], teachers' teaching performance is said to be of quality if a teacher can display good behaviour in his teaching efforts.

In line with Fitria, et al [7], a low level of teacher success induced by problems or disputes that arise between teachers is one of the educational issues facing the Indonesian nation to date. When teachers experience problems or conflicts between teachers and teachers and school principals, teacher performance is declining. Teachers are trained educators whose main job is to educate, instruct, guide, guide, prepare, evaluate and evaluate early childhood students through formal education, basic education and high-school education.

Based on the above background, the researchers will examine the problem by doing a study entitled "The Influence of Leadership Behaviour and Work Ethics Principal Performance against Teachers Teaching Teachers in Public Elementary School District of Jirak Jaya Musi Banyuasin".

\section{METHODS}

Ex post- facto analysis refers to the previous treatment or vector independent manipulation used in this study, just to see the effect on the dependent variable [8]. This research involved all teaching staff/teachers in SD Negeri Jirak Jaya District, amounting to 17 State SDs consisting of 2 Public SDs with Accreditation A, 12 Public SDs with Accreditation B, and 12 Public SDs with Accreditation. C, as many as 3 State SD.

Samples were taken of 5 public elementary schools consisting of SD Negeri 1 Jirak with 11 teachers, SD Negeri 2 Jirak with 13 teachers, SD Negeri 1 Setia Jaya with 9 teachers, SD Negeri 2 Setia Jaya. with 8 teachers, and SD Negeri Bangkit Jaya with 9 teachers. The reason for taking the sample unit is limited to that number. It is to obtain school characteristics based on Accreditation A, B and C, which represent each school's population. Data were collected using a Likert scale model questionnaire. The data analysis technique used: 1) descriptive quantitative analysis technique; and 2) multiple regressions.

\section{RESULTS AND DISCUSSION}

\section{The effect of leadership on the performance of teaching}

The result showed that the Leadership Behaviour $\left(\mathrm{X}_{1}\right)$ of the Teaching Performance (Y) after analysis of data obtained by value $t_{\text {arithmetic }}(11.383)>t$ table $(2.011)$ at the significant level of $5 \%$ and a probability value $(\mathrm{p})$ of $0.000<0.05$. From the findings it could be inferred that leading behaviour $\left(\mathrm{X}_{1}\right)$ in SD Negeri Jirak Jaya District had a major impact on teaching performance $(\mathrm{Y})$. It can be said that Ho is refused and $\mathrm{Ha}$ is approved in this declaration. Moreover, it also describes the percentage of impact on teaching performance of Leadership behaviour $\left(\mathrm{X}_{1}\right)$ which is called the determination coefficient resulting from squaring $\mathrm{R}$. The decision coefficient (Adjust R Square) of 0.724 is derived from the table above, which means that the Leadership Behaviour $\left(\mathrm{X}_{1}\right)$ impact on Teaching Performance $(\mathrm{J})$ is $72.4 \%$; although other factors that were not studied in this analysis affect the remaining $27.6 \%$.

The results of this report are consistent with the test results of the title by Alpian, et al [9], " The Effect of Academic Supervision and Completeness of Teaching Administration on Teacher Teaching Quality ". The results of this study indicate that: (1) academic supervision has no impact on the teacher quality in Pemulutan Senior School; (2) teaching management completeness has an impact on the teaching quality of Pemulutan Senior School teachers; and (3) teacher supervision and teaching administration completeness simultaneously have an impact on every quality of Pemulutan State Senior High School teacher.

Behavior emphasizes more on what the leader does and how a leader carries out his functions. According to Syafaruddin and Asrul [10]. It's often target-oriented action. This means that the need to accomplish expectations drives the action. The standards of conduct are settled upon: (1) action is the source, (2) conduct is specifically targeted, (3) behavior can be detected and evaluated, (4) behavior cannot be directly observed (possessions and perceptions) and is necessary in the attainment of objectives, and (5) behavior is a driver. 


\section{Effect of Work Ethics on Teaching Performance}

The results showed that the Work Ethic $\left(\mathrm{X}_{2}\right)$ on the Teaching Performance (Y) after analysis of data obtained by value $\mathrm{t}_{\text {arithmetic }}(4.294)>\mathrm{t}_{\text {table }}(2.011)$ at the significant level of $5 \%$ and a probability value (p) of 0.000 $<0.05$. From these results, there is a significant effect of Work Ethic $\left(\mathrm{X}_{2}\right)$ on Teaching Performance (Y) in SD Negeri Jirak Jaya District. It can be seen from this comment that Ho is refused and $\mathrm{Ha}$ admitted. It also describes the percentage of work ethics' effect on teaching (Y) which is known as the determination coefficient, resulting from squaring $\mathrm{R}$. The coefficient of determination (Adjust R Square) of 0,262 is obtained from the above table, indicating the impact on teaching performance $(\mathrm{Y})$ is Work ethic $\left(\mathrm{X}_{2}\right)$ of $26,2 \%$, whereas other variables not included in this analysis affect the remainder $73,8 \%$.

The research results of this study are in line with the research results under Damayani, et al [5] titled "The impact of teacher performance motivation and work discipline." This paper suggests that: 1) job motivation has a substantial effect on teacher performance; 2) the work discipline has a significant effect on teacher performance; 3 ) the motivation for work and discipline in teacher performance are significantly influence.

Work ethic is a teacher's professional attitude. According to Mabyarto [11], the work ethic is the attitude of the community towards the meaning of work as a driver of business success and development. Work ethic is a sociological phenomenon whose existence is formed by productive relationships that arise due to the existing economic structure in society. According to Sinamo [12] work ethic is referred to as spirit, mindset, and mentality which manifests into a set of distinctive and quality work behaviours.

\section{The Effect of Leadership Behaviour and Work Ethic on Teaching Performance}

The results shown that after data processing, the Fvalue was determined (15.143)> $\mathrm{F}$ table, following Leadership Behaviour $\left(\mathrm{X}_{1}\right)$ and Work Ethics $\left(\mathrm{X}_{2}\right)$ for Teaching Performance (Y) (3.19). The meaning test then got Sig $=0,000<0.05$. The Sig worth test. Hypothesis 3 findings show that Leadership Behaviour $\left(\mathrm{X}_{1}\right)$ and Work Ethic $\left(\mathrm{X}_{2}\right)$ have major parallel influence on teaching performance $(\mathrm{Y})$. It describes also the percentage of control on the dependent variable (the teaching performance), which is called the determination coefficient resulting from squaring $\mathrm{R}$, of the indigenous variables (leadership behaviour and work ethic). From the above table the determination coefficient (Adjust R Square), is 0.724 which means that the effect on the dependent variable (Leadership Behaviour) is $72.4 \%$ (Leadership Behaviour and Work Ethic), while the remaining $27.6 \%$ is determined by other factors that are not discussed in this analysis.

The findings of this analysis are consistent with research findings by Alhusaini [4] entitled "The impact of lead and motivation of work on teacher performance." The findings of the study indicate: (1) the principal leadership has a substantial impact on teaching performance; (2) the encouragement of teacher jobs influences considerably; and (3) the co-existence of the principal leadership is significantly affected by motivation for the work of teachers.

Likewise, the results of other studies conducted previously by [13] entitled, " The Effect of Principal Leadership Behaviour and Community Participation on the Implementation of Education in SMP Negeri 11 Prabumulih". The results of this study indicate that: 1) There is an influence in SMP Negeri 11 Prabumulih's leadership behavior over the implementation of education, which means that the leadership conduct of SMP Negeri 11 Prabumulih will impact the implementation of education; 2) Community participation has an effect on the implementation of education in SMP Negeri 11. The leadership behaviour of the main participation and participation in the group will thus influence education delivery. Leadership attitudes and group involvement will demonstrate a $24.2 \%$ commitment association with the delivery of education. Compared to the $75.8 \%$ left, the variables not present in this analysis are affected.

\section{CONCLUSION}

Based on data analyzes, it can be concluded that: 1) teachers' leadership behavior has an influence on teacher teaching performance; 2) teacher work ethics has an effect on teacher education; and 3) the main leading behavior and teacher ethics affects teacher teaching performance at the same time as teacher teachers and teaching teachers with a value of $F(15,143)$ Leadership Comportment and Work Ethics impact the teaching performance by 72.4 percent, while other factors not studied influence the remaining 27.6 percent.

\section{ACKNOWLEDGMENT}

Our deepest gratitude goes to Teachers in SD Negeri 3 Setia Jaya, Chancellor of Palembang PGRI University, Director of the Postgraduate Program of PGRI Palembang University and the Education Management Study Program of PGRI Palembang University, who have supported us in doing this extraordinary thing. This project is funded independently. We also want to thank our Education Management friends who helped us a lot in a short time frame to complete this project. 


\section{REFERENCES}

[1] Wahjosumidjo. (2012). Kepemimpinan Kepala Sekolah [Principal Leadership]. Jakarta: PT. Raja Grafindo Persada.

[2] Dahlan, M, Arafat, Y., \& Eddy, S. (2020). Pengaruh Budaya Sekolah dan Diklat terhadap Kinerja Guru [The Influence of School Culture and Education and Training on Teacher Performance]. Journal of Education Research, 1(3), 2020, Pages 218-225.

[3] Fitria, H., Meynita., \& Nurkhalis. (2020). Pengaruh Kemampuan Manajerial Kepala Sekolah dan Iklim Kerja Terhadap Kinerja Guru [The Influence of Principal Managerial Ability and Work Climate on Teacher Performance]. Jurnal Pendidikan Tambusai, 4(3).

[4] Alhusaini, A., Kristiawan., M., \& Eddy, S. (2020). Pengaruh Motivasi Kerja dan Disiplin Kerja terhadap Kinerja Guru [The Effect of Work Motivation and Work Discipline on Teacher Performance]. Jurnal Pendidikan Tambusai, 4(3).

[5] Damayani, T, Arafat, Y., \& Eddy, S. (2020). Pengaruh Kepemimpinan Kepala Sekolah dan Motivasi Kerja terhadap Kinerja Guru [The Influence of Principal Leadership and Work Motivation on Teacher Performance]. Journal of Innovation in Teaching and Instructional Media, Vol. 1 No. 1, September 2020 Page:46-57.

[6] Maharani, D. (2015). Pengaruh Perilaku Kepemimpinan Kepala Sekolah Dan Motivasi Kerja Terhadap Kinerja Mengajar Guru TK [The Influence of Principal Leadership Behavior and Work Motivation on Teaching Performance of Kindergarten Teachers]. Jurnal Online. Jurnal Administrasi Pendidikan Vol.XXII No.1 April 2015.

[7] Fitria, H., Ernaliza., \& Fitriani, Y. (2020). Peranan Manajerial Kepala Sekolah dalam Mengatasi Konflik Guru [Principal's Managerial Role in Addressing Teacher Conflict]. Journal of Education Research, 1(3), 2020, Pages 245-250.

[8] Sudjana, N., \& Ibrahim. (2010). Penelitian dan Penilaian Pendidikan [Educational Research and Assessment]. Bandung: Sinar Baru Algesindo.

[9] Alpian., Harapan, E., \& Kesumawati, N. (2020). Pengaruh Supervisi Akademik Dan Kelengkapan Administrasi Mengajar Terhadap Kualitas Mengajar Guru [The Effect of Academic Supervision and Completeness of Teaching Administration on Teacher Teaching Quality]. Jurnal Cahaya Pendidikan, Vol 6 No.1: 25-37.

[10] Syafaruddin., \& Asrul. (2017). Kepemimpinan Pendidikan Kontemporer [Contemporary
Educational Leadership]. Bandung: Cita Pustaka Media.

[11] Mabyarto. (2011). Etos Kerja dan Khesi Sosial [Work Ethic and Social Specialties]. Yogyakarta: Aditiya Media.

[12] Sinamo, J. (2011). 8 Etos Kerja Profesional [8 Professional Work Ethics]. Jakarta: Institut Dharma Mahardika.

[13] Rahmayani. A, Arafat. Y, Mulyadi. (2020) Pengaruh Perilaku Kepemimpinan Kepala Sekolah dan Partisipasi Masyarakat Terhadap Penyelenggaraan Pendidikan Di SMP Negeri 11 Prabumulih [The Effect of Principal Leadership Behavior and Community Participation on the Implementation of Education at SMP Negeri 11 Prabumulih]. Jurnal Kepemimpinan dan Pengurusan Sekolah. Vol 5, No 2. 